FACTA UNIVERSITATIS

Series: Physical Education and Sport Vol. 16, Nº 1, 2018, pp. 107 - 126

https://doi.org/10.22190/FUPES170927010P

Research article

\title{
FACTOR ANALYSIS AS AN OPTIMAL METHOD IN DETERMINING THE MOTOR ABILITIES AND THE QUALITY OF LIFE, HEALTH AND SOCIAL WELLNESS OF PERSPECTIVE JUDOKAS
}

\author{
UDC 61:-056.24 \\ 61:-053.5
}

\section{Dragan Popović ${ }^{1}$, Dragana Mitić ${ }^{1}$, Jasna Popović ${ }^{1}$, Evagelija Boli ${ }^{1}$, Evdokia Samouilidou ${ }^{2}$, Milan Dolga ${ }^{3}$}

${ }^{1}$ Faculty of Sport and Physical Education, University of Priština, Serbia

${ }^{2}$ School Supervisor for Physical Culture - Northern Aegean Region, Athens, Greece

${ }^{3}$ Agency for Multivariate Data Analysis, "Smart Line” Novi Sad, Serbia

\begin{abstract}
The goal of this study is a comparative analysis of the possibilities of physical education for children with health problems and the current status in boys and girls. Understanding the concept of impaired health is a precondition for the realization of the training process and possible integration in the process of physical education, according to the structure of health disadvantages. Quality of life assessment is performed on three levels. The first level are items that are given in the form of a statement. On the second level, item-like particles are observed in the sub-segments (scales that cover different dimensions of health and quality of life). The raw scores of each scale are transformed into standardized ones with a possible value of 1-4, which facilitates the interpretation of the results. The third level represents total physical and psycho-social health. Up to this level, there are certain mathematical procedures, based on the individual scale scores. Comparative analyses in regard of the cultural and gender specificities are provided, based on MANOVA and DISCRA analyses, within the introductory part, and 11 scales of the Questionnaire. Analysis of the data point out major differences in the possibility of physical activity application in children with medical conditions, with a special overview of boys and girls from diverse cultural and social backgrounds, in Serbia and the Northern Aegean region of Greece.
\end{abstract}

Key words: School children, Health impairment, Questionnaire, Self-evaluation, Cultural and Gender Comparison

Received September 27, 2017 / Accepted March 23, 2018

Corresponding author: Dragan Popović

Faculty for Sport and Physical Education, Universitiy of Priština, St. Dositeja Obradovića n.n., 38218

Leposavić, Serbia

Phone: +381 (0)28-84-700 • E-mail: dragan.popovic@pr.ac.rs 


\section{INTRODUCTION}

Quality of life, from the contemporary aspect of studying has an important place in the practice of health care and scientific-research work, and has long been discussed within the framework of social sciences by sociologists. That quality of life is mostly associated with the economic status of individuals and feelings. Quality of life defined by sociologists mainly means a set of parameters which include the physical and emotional status, vitality, functionality, personal and spiritual fulfillment, the adequacy of housing and nutrition, employment, social integration, social environment and positive support of the social environment (Dictionary of Sociology, 2007:281). In line with this approach, health is only one component of a broader concept.

With the development of society, the indicators of quality of life are being developed, so that in addition to the economic situation, spiritual values are evaluated as well, such as satisfaction, personal development and community affiliation. The subjective indicators of the quality of life are connected with a feeling, that is, emotional well-being and life satisfaction, while the real situation is assessed with economic indicators.

Large interest within medicine for the quality of life, is hardened by the development of the science of health and health care, from the moment when the WHO (World Health Organization), defined health as "a state of complete physical, mental and social well-being and not simply the absence of disease and disability" (according to Kvrgić, S., 2001, p. 10).

Although the idea of assessing quality of life by using various measuring instruments is widely accepted by researches in different areas, yet has no unique definition. As a result, the indicators of the quality of life are not clearly defined, but include wide range of different measures, with a little difference between the scales for the assessment of the quality of life, and those for measuring overall health. However, many authors observe quality of life as a complex function that contains more areas or domains of life and work of individuals, including physical and social function, mental status and type of symptoms, or health problems and individual perceptions of health.

Development of different sport skills and motor dimensions are closely related to quality of life. It is obvious that judokas need to have a high level of energy production to satisfy the energy demands of the bouts (Franchini, Takito, Kiss, \& Sterkowicz, 2005; Sertić, Segedi, \& Žvan, 2007; Sertic, Sterkowicz, \& Vuleta, 2009). The most reliable way of rating judokas' skill levels are their scores achieved during judo competitions (Obminski et al. 2015). Therefore, success in judo is dependent on a number of various well-used technical actions, mainly throws (Franchini et al. 2008; Obminski et al. 2015).

Some studies (Franchini et al. 2001a, 2001b; Krstulović, Žuvela, \& Katić, 2006; Milić et al. 2015) suggest that strength, coordination and aerobic-anaerobic endurance, may be crucial for judo performance. Lately, a hypothetical model of hierarchical motor dimension structure is a current model, which has been defined and suggested by Gredelj, Metikos, Hosek and Momirović (1975).

The aims of this pilot research are to carry out a structure analysis in the area of motor skills, as well as quality of life of primary school students in terms of the possibilities of physical activity application among children with health problems, and the presentation of the current status in the samples of respondents of different groups of ethnic origin (school children living in this country and abroad). 
The key aim, and the entire problem orientation of this research is related to the analysis of 20 motor tests (Popović, 1990) of 11 thematic sections (C1-C11) and 37 statements (items) within the segments of the questionnaire (Q) for the assessment of the Quality of life regarding Health and Social Wellness (QLHSW) components. The Convention on Children Rights, adopted (1989) by the United Nations (UN), point out that children have a right to health and well-being.

For this reason, the objective of this study is to assess all mentioned components of quality of life, using a comprehensive questionnaire. The specific objective is to assess some emotional and physical components of health, or consideration of the student's health situation which may affect their ability to engage in physical activities, as well as their sense of social well-being. The special interest of this study was to perform a comparative analysis of the gender differences in local sub-samples, as well as the analysis of different ethnicities of other groups. For that reason, we set the following tasks:

- To present the basic parameters of items within $11\left(\mathrm{C}_{1-} \mathrm{C}_{11}\right)$ segments of the Questionnaire in regard to the attitudes of two groups of respondents (with presentation of possible gender differences in the local sub-sample);

- To determine the differences in the statement modalities between two groups of different ethnic origin in relation to the applied items within particular segments of the Questionnaire (with a presentation of possible gender differences in the local sub-sample);

- To define the characteristics of each group of respondents (of different ethnic origin) in regard to the applied items within a particular segments $\left(\mathrm{C}_{1)-} \mathrm{C}_{11}\right)$ of the Questionnaire;

- To determine the contribution of the wholes (C) to the characteristics of the groups of different ethnic origin (Greece - GRE-1, Serbian -SER-2, samples of respondents).

Taking into account the previous experience, the key aim, and the presented problem orientation, as well as the methodological approach in this research, no difference between "group of the respondents of different ethnic origin", in relation to the tested items within certain segments of the questionnaire QLHSW, defined as a whole $\mathrm{C}_{1 \text { ) }}-\mathrm{C}_{11}$ ), was expected. A significant difference between "groups of the respondents of different ethnic origin", in relation to the tested items within certain segments of the questionnaire QLHSW, defined as wholes $\mathrm{C}_{1)}-\mathrm{C}_{10)}$, was expected.

- When it comes to gender differences within the local sub-samples (Boys-2, Girls2 groups), the research results will be provided only in the form of Contingency tables within 11 segments/wholes $\left(C_{1)}\right.$ to $\left(C_{11}\right)$ of the Questionnaire, and 37 items (research questions) with 4 levels of statements modalities, on a Likert-type scale.

Considering the small number of researchers working in this field in our home country, and region-wide, dealing with the estimation of the quality of life in children and youth, this study is partly based on the model, which was implemented by Kvrgić (2001), and published as a monograph Quality of life of school children and youth.

Important research in this area was conducted by Samouilidou (2004), and published as a monograph Stimulation of the motor development in pupils with mental retardation. 


\section{METHODS}

This comparative analysis provided an evaluation of the research results collected during the physical education classes in "Sveti Sava" Elementary school in Nis, and a group of foreign students in Greece.

Unlike the model, implemented in prior research (with two versions of the HSW Q), in this pilot study we only applied the questionnaire relating to the QLHSW components in older elementary school children (without consideration of the parental situation).

The studied variables are items. Characteristics of the divided sample into subsamples based on gender are the criterion. More items, which are connected to each other meaningfully and make a logical order are called simply (C), "whole" (segment/scale).

All of the studied thematic sections make a field of examination in regard of the criterion differences (groups of different ethnic origin).

\section{The research sample}

The total sample of 45 older elementary school students of both genders, divided into two samples according to different ethnicity: Total-GRE-1 $(\mathrm{N}=15)$ students of foreign (Greek) nationality (from the Northern Aegean Region), not very balanced in terms of gender: 13 male and 15 female students, aged from 10-11 to 15-16 years old, and TotalSRB-2 (N=30) local students, Serbian citizens, from Nis (well balanced in terms of gender: 15 male, and 15 female students), aged from 10-11 to 14-15 years old, respectively.

\section{Measuring Instrument}

The questionnaire $(\mathbf{Q})$ is designed to assess QLHSW. The introductory part of the $(\mathbf{Q})$ contains (1-7) items dealing with some socio-demographic indicators regarding the family members of the respondents. The rest of the $(\mathbf{Q})$ refers to the statements of the respondents in terms of applied segments/wholes (C), in total eleven, and offered four modalities (degrees) on a Likert-type scale ranging from 1-4 for intensity. Names and descriptions of certain scale are provided according to Kvrgić (2001): pp. 22-24 (Source: The CHQ User's Manual. Landgraf, Ware, \& Abetz, 1996).

\section{Area of research}

The introductory part of the QLHSW-Questionnaire relates to some demographic and social status variables of elementary school students and their parents, assessed by seven segments (1-7). All of the obtained data were analyzed only on the basis of absolute and relative frequencies within the segments, and provided items on gender, age, level of education and professional position of children (when applicable), and their parents.

The main area of this research consists of 11 thematic sections $\left(C_{1}-C_{11}\right)$ which are analyzed in relation to different groups/samples, related to ethnic specificity comparison (GRE-1; SRB-2): $\mathrm{C}_{1}-$ Scale of physical functioning: (SPF8-SPF10); $\mathrm{C}_{2}-$ Scale of social role implementations: (SSR11-SSR12); $\mathrm{C}_{3}-$ Scale of Global health: (SGH13-GH15); $\mathrm{C}_{4}-$ Scale of bodily pain: (SBP16-SBP17); $\mathrm{C}_{5}-$ Scale of the psychological impact on parents: (SPI18SPI19); $\mathrm{C}_{6}-$ Scale of social roles implementation: (SSR20-SSR23); $\mathrm{C}_{7}-$ Scale of selfassessment: (SES24-SES28); $\mathrm{C}_{8}-$ Scale of Mental Health: (MHS29-MHS30); $\mathrm{C}_{9}-$ Scale of behavior: (BHS31- BHS33); C10 - Scale of family activities health changes: (SHC37); C11- segment of HSW-Q, refers to the Scale of Health Change (L): (SHC 37). 


\section{Mathematical-Statistical model of data processing}

The data were processed with the appropriate mathematical and statistical procedures, and their order of application, which is of the highest importance, both for the conclusion, and for the proper elimination, or the inclusion of certain variables, which will enable us to improve the quality of the research results explanation. The analysis was conducted in three steps as follows: hypothesis testing about the similarities or differences, specifying measures of the differences, and defining characteristics.

\section{Applied processes}

Variables of the segments (wholes) $\mathrm{C}_{1-} \mathrm{C}_{11}$, with applied items (37 in total), have nonparametric properties and accordingly are analyzed with nonparametric methods, in regard to the frequency and modalities of the statements. For the purpose of data analysis, multivariate procedures were used: Multivariate Analysis of Variance (MANOVA) and Discriminative Analysis (DISCRA). From univariate methods we applied Roy's test, Pearson's coefficient of contingency $(\chi)$, and the multiple correlation coefficient $(\mathrm{R})$.

The purpose of the application of mathematical and statistical analyses aims to determine the characteristics of the samples homogeneity, and the distance between them in relation to the estimated criterion characteristics, for the reliable and accurate prediction and prognosis of a positive significance.

\section{RESULTS}

To avoid losing information, finding the finest links and information on nonparametric values, data scaling is performed on the tables of contingency. This procedure, based on the unit frequency, for each class is given a real number, which reflects the intensity of item modalities within certain segments of the questionnaire.

\section{Structure of motor factors}

The correlations between manifest and latent variables, defined as oblimin factors are given in table 1.

The factorial structure of the motor variables was analyzed concurrently, based on all the information which provided an orthoblique transformation of significant main components, that is, on the basis of a variable correlation matrix and factors (table 1).

The first factor is, according to the variance value, the most important one of the isolated dimensions. Its position in the coordinate system (obtained by the orthoblique transformation) is a general motor factor. Apart from the tests for the force assessment (MFLIP, MDSAK), all the other tests have significant correlations with this dimension. 
Table 1

\begin{tabular}{lccc}
\hline & AREA1 & AREA2 & AREA3 \\
\hline Agility with bat (AWB) (s) & .64 & .00 & -.31 \\
Jump with 3kg medicine ball (J3MB) (cm) & .48 & -.37 & -.28 \\
Hand tapping (HT) (freq) & -.41 & .28 & -.13 \\
Leg tapping (LT) (freq) & -.68 & .35 & .07 \\
Polygon (POL) (s) & .85 & -.21 & -.26 \\
Flexibility assessment test (FAT) (cm) & -.60 & .23 & .49 \\
Transversely standing on the bench (TSOB) (s) & -.75 & .19 & .08 \\
Longitudinally standing on the bench (LSOB) (s) & -.65 & .07 & .05 \\
Endurance in push up (EIPU) (s) & .49 & .09 & -.45 \\
The splits (SPAG) (cm) & -.58 & .59 & .22 \\
Jump with both legs with a medicine ball (JBLM) (cm) & -.73 & .64 & .40 \\
20m running standing start (20mR) (s) & .51 & -.30 & .28 \\
Throwing medicine ball from lying position (TMBL) (cm) & -.11 & .84 & -.08 \\
Push-ups (PU) (freq) & -.98 & .11 & .39 \\
Lifting legs lying down (LLLD) (cm) & -.28 & .10 & .84 \\
Sit ups (SU) (freq) & -.69 & .35 & .31 \\
Endurance legs on the chest (ELOC) (s) & -.71 & .11 & .35 \\
Endurance troops in lead (ETIL) (s) & -.24 & -.12 & -.23 \\
Hand dynamometry (HD) (kg) & -.35 & .82 & .08 \\
Spark stick (SS) (cm) & -.21 & .81 & -.04 \\
\hline
\end{tabular}

As it is not in a child's nature to solve motor tasks in which a high intensity energetic component prevails, and so-called 'explosive strength' is more a characteristic of CNS which, because of significant genetic predetermination, cannot be influenced, what remains is to analyze the problem of general motor ability of pioneer judokas by means of information components of motor tasks. This primarily refers to the structuring of movement (with different types of coordination) regulating the involvement of agonist and antagonist muscles and regulating muscle tone.

Functionally speaking, general motor ability in children in this period of development probably depends on the effective function of the entire CNS. This efficacy is reflected in the quality of receptors, especially of kinesthetic, muscular, tendonal, afferent paths, decoders in the cortical and subcortical part of CNS, then in corticospinal and subcorticospinal paths, front motor neurons of the spinal cord, motor units and the entire muscle effector (Popovic, 1993 and 2016).

The ability of manifesting greater physical strength at this age is not prominent. This primarily refers to generating muscle strength which is to move the body to another position. All contractions of isotonic and isometric character necessary for the realization of motor tests applied in the program of motor measurements provide information about the so-called 'relative strength' and give the assessment of the corresponding muscle endurance. However, it is certain that such a partial motor ability is not developed enough, which is a completely normal characteristic in ontogenetic development of man.

Since the speed of solving and performing complex motor tasks is an essential feature of the content of most of the tasks, which still best define this dimension, it could be concluded that at the basis of this dimension lies the mechanism for structuring movements. 
The second dimension is defined by: throwing a medicine ball from a lying position, left forearm flexion, hand dynamometer, the standing long jump, and the split. The common feature of the aforementioned tests, except the last one, is a short-term muscle contraction caused by the maximum excitation of the central nervous system, which causes the excitation of the maximum possible number of motor units. This type of muscle action results in a quick and explosive force development, and this dimension is most often defined as explosive strength. The projection of the variable of throwing a medicine ball from a lying position also confirms the definition of the factor. The distance range is proportional to the square of the velocity of the throw (without considering other factors here).

The features of the tests - hand dynamometer and left forearm flexion develop maximum force possible under normal conditions (in so called 'attempted moves'). However, it must be emphasized that the final input does not depend only on the current agonist activation, but, in fact, on the cumulative effect of successive involvement of a larger number of motor units that the maximum number of muscle fibers is activated at the moment of maximum tension. During that, muscles are activated that generate force whose direction is not in accordance with the activated agonists, but serve to provide as much support as possible (that is, as fixators). Maximum muscle strength depends on the number of activated muscle units, and that number is obviously independent of neither the number of available units that can be activated at all nor, therefore, of the active muscle mass.

So the results in these tests do not only depend on the functional characteristics of the effector and on the excitability of the motor cortex, but also on the performance of subcortical centers that modulate the impulses from the motor cortex (1990 and 1993).

The third dimension is not clearly defined. Lifting legs while lying down (LLLD), the $20 \mathrm{~m}$ run with a standing start $(20 \mathrm{mR})$ and the flexibility assessment test (FAT) have the greatest projections on this dimension. The characteristic of the first test is that it requires long-term muscle strain, which in this case is obviously a discontinuous strain (repetition tests). The characteristics of the second test is the possibility of developing great excitation in primary motor centers in the brain cortex and in those subcortical nuclei that function as amplifiers and efferent information modulators. In this case, this dimension can be explained by the character of the movement regulation in primary motor centres and subcortical nuclei of the CNS.

Since this dimension is highly correlated with the test LLLD, it could be defined, with certain caution, as a latent functional structure that is responsible for regulating the duration of the excitation of the primary motor centers that control the movements of the active muscles (1990 and 1993).

\section{Survey of the introductory part of $(Q)$ within 7 segments (43 items) in regard to the different "Groups" of ethnic origin, and gender specificity comparison}

In Introductory Table A, segments ADSS (1-7) provide the primary school students' basic social status components, and some demographic data on local (SRB-2) and foreign country (GRE-1) participants, and their parents (where applicable). 
Table A. The Student's Social Status - ADSS (1-7)

\begin{tabular}{|c|c|c|c|c|}
\hline$(\mathrm{A}-\mathbf{- 0 1})$ & \multicolumn{4}{|c|}{ Gender } \\
\hline SRB-2 / Sub-samples / GRE-1 & TOT (SRB-2) & Boys-2 & Girls-2 & TOT (GRE-1) \\
\hline Male-2 (15) Female-2 (15) & $100 \%$ & $50 \%$ & $\mathbf{5 0 \%}$ & $80 \%(20 \%)$ \\
\hline$\underline{(\mathrm{A}-02)}$ & \multicolumn{4}{|c|}{ Child parenting } \\
\hline SAMPLE / Sub-samples & TOT (SRB-2) & Boys-2 & Girls-2 & TOT (GRE-1) \\
\hline Both parents & $83.3 \%$ & $80 \%$ & $86.7 \%$ & $73.3 \%$ \\
\hline Mother & $16.7 \%$ & $20 \%$ & $13.7 \%$ & $20 \%$ \\
\hline Father & $(-)$ & $(-)$ & $(-)$ & $6.7 \%$ \\
\hline$\overline{(\mathrm{A}-03)}$ & \multicolumn{4}{|c|}{ Age of the Children } \\
\hline SAMPLE / Sub-samples & TOT (SRB-2) & Boys-2 & Girls-2 & TOT (GRE-1) \\
\hline $\mathrm{c}(10-11)$ & $6.7 \%$ & $13.3 \%$ & $(-)$ & $(-)$ \\
\hline $\mathrm{d}(12-13)$ & $66.7 \%$ & $60 \%$ & $73.3 \%$ & $13.3 \%$ \\
\hline e (14-15) & $26.7 \%$ & $26.7 \%$ & $26.7 \%$ & $60 \%$ \\
\hline $\mathrm{f}(16-17)$ & $(-)$ & $(-)$ & $(-)$ & $26.7 \%$ \\
\hline (A-04) & \multicolumn{4}{|c|}{ Age of the Parents } \\
\hline SAMPLE / Sub-samples & TOT (SRB-2) & Boys-2 & Girls-2 & TOT (GRE-1) \\
\hline Father (years) & 48.2 & 47.1 & 49.1 & 43.8 \\
\hline Mother (years) & 41 & 38.4 & 43.7 & 41.7 \\
\hline $\begin{array}{l}\mathbf{A - 0 5}) \\
\end{array}$ & \multicolumn{4}{|c|}{ Grade level of Children } \\
\hline SAMPLE / Sub-samples & TOT (SRB-2) & Boys-2 & Girls-2 & TOT (GRE-1) \\
\hline VIth (10-11) & $\mathbf{7 0 \%}$ & $73.3 \%$ & $66.7 \%$ & $(-)$ \\
\hline VIIth (12-13) & $(-)$ & $(-)$ & $(-)$ & $13.3 \%$ \\
\hline VIIIth (14-15) & $30 \%$ & $26.7 \%$ & $33.3 \%$ & $40 \%$ \\
\hline IXth (16-17) & $(-)$ & $(-)$ & $(-)$ & $46.7 \%$ \\
\hline (A-06a) & \multicolumn{4}{|c|}{ Educational Level of Parent - Father (A) } \\
\hline SAMPLE / Sub-samples & TOT (SRB-2) & Boys-2 & Girls-2 & TOT (GRE-1) \\
\hline (II) Completed primary School & $7.2 \%$ & $13.3 \%$ & $(-)$ & $(-)$ \\
\hline (III) Incomplete-Sec/Vocational & $3.6 \%$ & $6.7 \%$ & $(-)$ & $6.67 \%$ \\
\hline (IV) Sec-School Diploma & $28.6 \%$ & $26.7 \%$ & $28.6 \%$ & $60 \%$ \\
\hline (V) College & $28.6 \%$ & $30 \%$ & $35.7 \%$ & $(-)$ \\
\hline (VI) High School Education & $32.1 \%$ & $33.3 \%$ & $28.6 \%$ & $33.3 \%$ \\
\hline (A-06b) & \multicolumn{4}{|c|}{ Educational Level of Parent - Mother (B) } \\
\hline SAMPLE / Sub-samples & TOT (SRB-2) & Boys-2 & Girls-2 & TOT (GRE-1) \\
\hline (II) Completed primary School & $10.7 \%$ & $13.3 \%$ & $6.7 \%$ & $(-)$ \\
\hline (III) Incomplete-Sec/Vocational & $(-)$ & $(-)$ & $(-)$ & $(-)$ \\
\hline (IV) Sec-School Diploma & $21.4 \%$ & $30 \%$ & $20 \%$ & $(-)$ \\
\hline (V) College & $32.1 \%$ & $13.3 \%$ & $46.7 \%$ & $(-)$ \\
\hline (VI) High School Education & $35.7 \%$ & $40 \%$ & $46.7 \%$ & $(-)$ \\
\hline (A-07a) & \multicolumn{4}{|c|}{ Occupation of Parent - Father (A) } \\
\hline SAMPLE / Sub-samples & TOT (SRB-2) & Boys-2 & Girls-2 & TOT (GRE-1) \\
\hline (I) Unemployed & $7.1 \%$ & $7.1 \%$ & $7.1 \%$ & $6.67 \%$ \\
\hline (II) Housewife/Farmer & $(-)$ & $(-)$ & $(-)$ & $(-)$ \\
\hline (III) Wage worker/ laborer & $3.6 \%$ & $7.1 \%$ & $(-)$ & $(-)$ \\
\hline (IV) Industrial Worker/Craftsman & $(-)$ & $6.1 \%$ & $(-)$ & $(-)$ \\
\hline (V) Civil servant / Entrepreneur & $50 \%$ & $50 \%$ & $50 \%$ & $60 \%$ \\
\hline (VI) Manager / Businessman & $17.8 \%$ & $21.4 \%$ & $14.3 \%$ & $13.3 \%$ \\
\hline (VII) Other (specify profession) & $21.4 \%$ & $14.3 \%$ & 28.6 & $20 \%$ \\
\hline
\end{tabular}




\begin{tabular}{lcccc}
\hline (A-07b) & \multicolumn{4}{c}{ Occupation of Parent - Mother (B) } \\
\hline SAMPLE / Sub-samples & TOT (SRB-2) & Boys-2 & Girls-2 & TOT (GRE-1) \\
(I) Unemployed & $15.4 \%$ & $6.7 \%$ & $20 \%$ & $(-)$ \\
\hline (II) Housewife/Farmer & $11.5 \%$ & $14.3 \%$ & $6.7 \%$ & $(-)$ \\
(III) Wage worker/Laborer & $3.85 \%$ & $(-)$ & $6.7 \%$ & $(-)$ \\
(IV) Industrial Worker/Craftsman & $3.85 \%$ & $6.7 \%$ & - -) & $(-)$ \\
(V) Civil servant / Entrepreneur & $38.5 \%$ & $\mathbf{2 9 \%}$ & $40 \%$ & $(-)$ \\
(VI) Manager / Businessman & $3.3 \%$ & $\mathbf{6 . 7 \%}$ & $(-)$ & $(-)$ \\
(VII) Other (specify profession) & $20.7 \%$ & $\mathbf{2 1 . 4 \%}$ & $20 \%$ & $(-)$ \\
\hline
\end{tabular}

Survey on the Quality of Life, Health and Social Wellness (Q) within eleven segments [C1-C11] and provided 37 items in regard to the different "Groups" of Ethnic origin, and home country "Gender" specificity comparison

B- $\mathrm{C}_{1}$ - The scale of physical functioning: $(\mathrm{H}-8, \mathrm{I}-9, \mathrm{~J}-10)$, measures the presence and extent of physical limitations caused by health problems, and includes three important dimensions: self-care, mobility and activities that require more effort. The presence and degree of limitation is estimated on a 4-point Likert-type scale, from "very limited" to "not limited". A low score indicates that health problems significantly limit the child in performing all physical activities (PA), whereas a high score means that a child performs physical activity without restrictions.

Table 1 The Scale of Physical Functioning - B-SPF (8-10)

\begin{tabular}{|c|c|c|c|c|}
\hline \multicolumn{5}{|c|}{$\begin{array}{l}\text { (H-8) Is independent students care about them limited due to health conditions? } \\
\end{array}$} \\
\hline SAMPLES & TOT (SRB-2) & Boys-2 & Girls-2 & TOT (GRE-1) \\
\hline Not limit & $72.3 \%(4) *$ & $64 \%$ & $80 \%$ & $26.7 \%$ \\
\hline Partially restricted & $24.3 \%$ & $29 \%$ & $20 \%$ & $33.3 \%$ \\
\hline Mostly limited & $3.4 \%$ & $7.1 \%$ & $(-)$ & $40 \%(2)^{*}$ \\
\hline Very limited & $(-)$ & $(-)$ & $(-)$ & $(-)$ \\
\hline \multicolumn{5}{|c|}{ (I-9) How many daily activities are limited because of student's physical health? } \\
\hline SAMPLES & TOT (SRB-2) & Boys-2 & Girls-2 & TOT (GRE-1) \\
\hline Not limit & $83 \%(4) *$ & $80 \%$ & $80 \%$ & $33.3 \%$ \\
\hline Somewhat limited & $6.9 \%$ & $(-)$ & $13.3 \%$ & $20 \%$ \\
\hline Occasionally limited & $10 \%$ & $20 \%$ & $6.7 \%$ & $46.7 \%(2)^{*}$ \\
\hline Very limited & $(-)$ & $(-)$ & $(-)$ & $(-)$ \\
\hline \multicolumn{5}{|c|}{$\begin{array}{l}\text { (J-10) How much health status influenced the performance of physical activities that require } \\
\text { more effort? }\end{array}$} \\
\hline SAMPLES & TOT (SRB-2) & Boys-2 & Girls-2 & TOT (GRE-1) \\
\hline No restrictions & $(75.8 \%(4) *$ & $\mathbf{7 8 . 6 \%}$ & $73.3 \%$ & $40 \%$ \\
\hline Partially restricts & $6.9 \%$ & $(-)$ & $13.3 \%$ & $26.7 \%(2)^{*}$ \\
\hline Occasionally restricts & $10.3 \%$ & $14.3 \%$ & $6.7 \%$ & $33.3 \%(3)^{*}$ \\
\hline Completely restrict & $6.9 \%$ & $7.1 \%$ & $6.7 \%$ & $(-)$ \\
\hline
\end{tabular}

Note: In parenthesis are marked statements modalities up (1)* to (4)*, within some items, which contributed (ctrb.\%) to the statistically significant between "groups" differences: MANOVA ( $\mathrm{F}=6.74, \mathrm{p}=.001)$; DISCRA $(\mathrm{F}=6.57, \mathrm{p}=.001)$. Homogeneity: GRE-1: 10/15 (66.7\%); SRB-2: 25/30 (83.3\%), Ctrb. (\%): H-8 (69.7); 
The Scale of Physical Functioning B-SPF (8-10) presented relative values within items (H-8, I-9, J-10), and provided statements, with no significant gender difference between home country sub-samples (Boys-2; Girls-2), while the majority of both samples opted for the statement on "no restrictions" in independent students care about themselves-due to health conditions; daily physical activities; and those performance of physical activities that require more effort.

C-C $\mathbf{C}_{\mathbf{2}}$ - Scale of social roles implementation: SSR11, SSR12). Accomplishing, and the realization of the social role previously mainly estimated on the basis of absences from school, and now is considered of great importance for the ability to socialize and get along with others. Accordingly, these 4-point scales assess to which extent physical health interferes with children's everyday school activities and contact with their friends. The low score points out the high degree of restrictions, while high score means that there is no restriction.

Table 2 The Scale of Social Role Implementation -SSRI - (11-12)

\begin{tabular}{lcccc}
\hline \multicolumn{5}{l}{ (K-11) The extent to which physical health interfere with everyday school activities? } \\
\hline SAMPLES & TOT (SRB-2) & Boys-2 & Girls-2 & TOT (GRE-1) \\
\hline No restrictions & $62.1 \%(4) *$ & $69.2 \%$ & $60 \%$ & $33.3 \%$ \\
Partially restricted & $13.7 \%$ & $15.4 \%$ & $13.3 \%$ & $40 \%(3)^{*}$ \\
Occasionally restricted & $20.7 \%$ & $15.4 \%$ & $26.7 \%$ & $26.7 \%$ \\
Very restricted & $3.4 \%$ & $(-)$ & $(-)$ & $(-)$ \\
\hline (L-12) The extent to which students' physical health disrupts daily social activities \\
\hline \multicolumn{5}{l}{ SAMPLES } \\
\hline No restrictions & TOT (SRB-2) & Boys-2 & Girls-2 & TOT (GRE-1) \\
Partially restricted & $76.9 \%(4) *$ & $76.9 \%$ & $66.7 \%$ & $26.7 \%$ \\
Occasionally restricted & $3.8 \%$ & $(-)$ & $13.3 \%$ & $46.7 \%(3)^{*}$ \\
Completely restricted & $11.5 \%$ & $15.4 \%$ & $6.7 \%$ & $26.7 \%$ \\
\hline
\end{tabular}

Note: In parenthesis are marked statements modalities up (1)* to (4)*, within some items, which contributed (ctrb.\%) to the statistically significant between "groups" differences: MANOVA ( $\mathrm{F}=10.32, \mathrm{p}=.000)$ ) DISCRA ( $\mathrm{F}=11.58$, p=.000). Homog.: GRE-1: 11/15 (73.3\%); SRB-2: 24/30 (80\%); Ctrb. (\%): L-12 (99.4), K-11 (.66).

The Scale of Social Role Implementation C-SSRI (11-12) presented relative values within items (K-11, L-12), and provided statements, with no established significant gender difference between local sub-samples (Boys-2; Girls-2), while the majority of both samples opted for the statement on "no restrictions" in the extent to which physical health interfere with everyday school activities; or extent to which physical health of students disrupts daily activities with friends.

D- $\mathbf{C}_{3}$ - The scale of global health: (M-13, N-14, O-15). In this part of the questionnaire the respondents subjectively evaluate past, present and future health status, as well as susceptibility to diseases, by expressing their agreement with the statements on the 4point scale. A low score means that the children's health is assessed as poor (very bad), with a worsening trend, whereas a high score is assigned when health is evaluated as excellent and the belief that it will remain so. 
Table 3 The Scale of the Global Health - D-SGH (13-15)

\begin{tabular}{|c|c|c|c|c|}
\hline \multicolumn{5}{|c|}{ (M-13) What is a subjective assessment of a students' health in the past year? } \\
\hline SAMPLES & TOT (SRB-2) & Boys-2 & Girls-2 & TOT (GRE-1) \\
\hline Excellent & $55.6 \%(4)^{*}$ & $83.3 \%$ & $33.3 \%$ & $33.3 \%$ \\
\hline Very good & $44.4 \%$ & $16.7 \%$ & $66.7 \%$ & $53.3 \%$ \\
\hline Occasionally poor & $(-)$ & $(-)$ & $(-)$ & $13.3 \%(2)^{*}$ \\
\hline Very bad & $(-)$ & $(-)$ & $(-)$ & $(-)$ \\
\hline \multicolumn{5}{|c|}{ (N-14) What is a subjective assessment of the current health status of students? } \\
\hline SAMPLES & TOT (SRB-2) & Boys-2 & Girls-2 & TOT (GRE-1) \\
\hline Excellent & $71 \%(4)^{*}$ & $85 \%$ & $60 \%$ & $33.3 \%$ \\
\hline Tendency to improvement & $21.4 \%$ & $7.7 \%$ & $33.3 \%$ & $33.3 \%$ \\
\hline Subject to disease & $7.1 \%$ & $7.7 \%$ & $6.7 \%$ & $33.3 \%(2) *$ \\
\hline Very bad & $(-)$ & $(-)$ & $(-)$ & $(-)$ \\
\hline \multicolumn{5}{|c|}{ (O-15) What is a subjective assessment of the future health of students? } \\
\hline SAMPLES & TOT (SRB-2) & Boys-2 & Girls-2 & TOT (GRE-1) \\
\hline Shall be great & $65.4 \%(4)^{*}$ & $75 \%$ & $57.1 \%$ & $33.3 \%$ \\
\hline Very good & $26.9 \%$ & $16.7 \%$ & $33.3 \%$ & $20 \%$ \\
\hline Tendency to improvement & $3.8 \%$ & $8.3 \%$ & $(-)$ & $46.7 \%(2)^{*}$ \\
\hline Bad, with deteriorating & $3.8 \%$ & $(-)$ & $6.7 \%$ & $(-)$ \\
\hline
\end{tabular}

Note: In parenthesis are marked statements modalities up (1)* to (4)*, within some items, which contributed (ctrb.\%) to the statistically significant between "groups" differences: MANOVA ( $\mathrm{F}=3.63, \mathrm{p}=.021)$; DISCRA $(\mathrm{F}=3.545, \mathrm{p}=.023)$. Homogeneity: GRE-1: 7/15 (46.7\%); SRB-2: 25/30 (83.3\%). Ctrb. (\%): O-15 (82.2), M13 (10.2), N-14 (7.6).

The Scale of the Global Health - D-SGH (13-15), presented relative values within items (M-13, N-14, O-15), and provided statements, with no established significant gender difference between local sub-samples (Boys-2; Girls-2), while the majority of both samples opted for the statement "Excellent" or "very good" when considering " $a$ subjective assessment of a students' health in the past year" or "a subjective assessment of the current health status of students" and "a subjective assessment of the future health of students" with some prevalence of higher percentage of statements in Boys-2-sample.

E- $\mathbf{C}_{4}$ - The scale of the bodily pain: (SBP16, SBP17), was designed to measure the intensity and frequency of pain, as one of the indicators of physical health. The pain or discomfort is assessed through responses ranging from "no pain" to "present a very strong pain" (with a time limit on the last 4 weeks, from the day of survey application). A low score means that the child feels extremely strong, frequent and restrictive pain, whereas a high score speaks of the absence of pain or restriction.

The Scale of Bodily Pain - E-SBP (16-17), presented relative values within items (P16, Q-17), and provided statements, with no established significant gender difference between local sub-samples (Boys-2; Girls-2), while the majority in both samples opted for the statement "no pain", when considering "a subjective assessment of pain as one of the indicators of health status of students" or "the frequency of the subjective assessment of pain as one of the indicators of health status of students" with some prevalence of higher percentage of statements in Boys-2 sub-sample. 
Table 4 The Scale of Bodily Pain - E-SBP (16-17)

\begin{tabular}{lcccc}
\hline (P-16) What is a subjective assessment of pain as indicator of student's health status? \\
\hline SAMPLES & TOT (SRB-2) & Boys-2 & Girls-2 & TOT (GRE-1) \\
\hline No pain & $\mathbf{6 8 \% ( 4 ) *}$ & $\mathbf{7 7 \%}$ & $\mathbf{6 0 \%}$ & $20 \%$ \\
Anxiety & $7.1 \%$ & $7.7 \%$ & $6.7 \%$ & $\mathbf{4 0 \%}(\mathbf{3}) *$ \\
Some pain & $21.4 \%$ & $15.3 \%$ & $26.7 \%$ & $26.7 \%$ \\
Presence of a strong pain & $3.6 \%$ & $(-)$ & $6.7 \%$ & $13.3 \%$ \\
\hline
\end{tabular}

\section{(Q-17) What is the frequency of the subjective assessment of pain as one of the indicators of} health status of students?

\begin{tabular}{lcccc}
\hline SAMPLES & TOT (SRB-2) & Boys-2 & Girls-2 & TOT (GRE-1) \\
\hline No pain & $\mathbf{5 7 \% ( 4 ) *}$ & $\mathbf{7 7 \%}$ & $\mathbf{4 6 . 7 \%}$ & $20 \%$ \\
Occasional discomfort & $30 \%$ & $23 \%$ & $40 \%$ & $\mathbf{7 3 . 3 \%}(\mathbf{3}) *$ \\
Almost every day pain & $13 \%$ & $(-)$ & $13.3 \%$ & $6.7 \%$ \\
Daily, very severe pain & $(-)$ & $(-)$ & $(-)$ & $(-)$ \\
\hline Note In parenthesi
\end{tabular}

Note: In parenthesis are marked statements modalities up (1)* to (4)*, within some items, which contributed (ctrb.\%) to the statistically significant between "groups" differences: MANOVA ( $\mathrm{F}=6.19, \mathrm{p}=.003)$; DISCRA ( $\mathrm{F}=6.65, \mathrm{p}=.003)$. Homogeneity: GRE-1: 12/15 (80\%); SRB-2: 22/30 (73.3\%). Ctrb. (\%): P-16 (79.65), Q-17 (20.35)

F-C $\mathbf{C}_{\mathbf{5}}-$ Scale of the emotional impact on the parents: (R18, S19). Surveys conducted in the late 1980s by foreign researches indicate a direct correlation between the estimated child health and the degree to which the parent feels physically and emotionally affected. In order to measure the impact of child health on parents there two scales of Time impact and Emotional impact have been constructed. The time impact scale assess the extent of the restriction period that the parent give to himself because of the child's physical health, emotional problems, attention abilities, or studying, the ability to come up with others and child behavior. The Scale has 4 points, and the responses range from "very limited" to "not limit". A low score points out on high degree of limitation in the time available for personal needs, due to the child's physical and/or psycho-social health. A high score means that a parent does not experience such restrictions. The scale of Emotional impact is about suffering and care of parents for the child's health. A low score points out the considerable emotional distress and serious concern because of the child's physical and/or psycho-social health, whereas a high score means that the concern and suffering do not exist (there are no limitations).

Table 5 The Scale of the Emotional Impact on Parents - F-SEIP (18-19)

(R-18) How do students assess parent's limited time for a personal need, because of children's physical and/or psychosocial health?

\begin{tabular}{lcccc}
\hline SAMPLES & TOT (SRB-2) & Boys-2 & Girls-2 & TOT (GRE-1) \\
\hline Very limited & $11.1 \%$ & $7.7 \%$ & $14.3 \%$ & $13.3 \%$ \\
Occasionally limited & $14.8 \%$ & $7.7 \%$ & $14.3 \%$ & $\mathbf{5 3 . 3 \% ( 2 ) *}$ \\
Partially limited & $7.4 \%$ & $(-)$ & $14.3 \%$ & $33.3 \%(3) *$ \\
Not limited & $\mathbf{6 6 . 7 \%}(\mathbf{1}) *$ & $\mathbf{7 7 \%}$ & $\mathbf{5 7 . 1 \%}$ & $(-)$ \\
\hline
\end{tabular}

(S-19) How do students assess parents suffering and worries because of children's physical and/or psychosocial health?

\begin{tabular}{lcccc}
\hline SAMPLES & TOT (SRB-2) & Boys-2 & Girls-2 & TOT (GRE-1) \\
\hline No worries & $24 \%(4) *$ & $30.8 \%$ & $16.7 \%$ & $(-)$ \\
Mild concern & $\mathbf{5 2 \% *}$ & $\mathbf{4 6 \%}$ & $\mathbf{5 8 . 3 \%}$ & $26.7 \%$ \\
Considerable care & $20 \%$ & $15 \%$ & $23.1 \%$ & $\mathbf{5 3 . 3 \%}(\mathbf{2}) *$ \\
Grave emotional concern & $4 \%$ & $7.7 \%$ & $(-)$ & $20 \%$ \\
\hline
\end{tabular}

Note: In parenthesis are marked statements modalities up (1)* to (4)*, within some items, which contributed (ctrb.\%) to the statistically significant between "groups" differences: MANOVA ( $\mathrm{F}=15.004, \mathrm{p}=.000)$; DISCRA ( $\mathrm{F}=17.68, \mathrm{p}=.000)$. Homogeneity: GRE-1: 14/15 (93.3\%); SRB-2: 21/30 (70\%). Ctrb. (\%): R-18 (70.8), S-19 (29.2). 
The Scale of the Emotional Impact on Parents - F-SEIP (18-19) presented relative values within items (R-18, S-19), and provided statements, with no established significant gender difference between local sub-samples (Boys-2; Girls-2), while the majority in both samples opted for the statement "not limited", when considering "How do students assess parents limited time for a personal needs, because of children's physical and/or psycho-social health" with some prevalence of higher percentage of statements in Boys-2 sub-sample, or for the statement of "mild concern" when it is about "How do students assess parents suffering and worries because of children's physical and/or psychosocial health?" with some prevalence of higher percentage of statements in Girls-2 sub-sample.

G - $\mathbf{C}_{6}$ - The scale of emotional state and bahavior: (T20, U21, V22, W23). For the realization of the social role, which includes daily activities, such as school activities, and social activities with friends, in addition to physical health is of the same importance as the emotional state and behavior. The Scales, which measure this effect have been constructed to include 4 points and can be separated, but also can be a unique-form scale that indicates the combined impact of emotions and behaviors for the realization of a social role. A low score means that the child is, because of his behavior or emotional problems, substantially limited in performing school or other daily activities with friends, while a high score means that there are no limitations.

Table 6 The Scale of Emotional State and Behavior - G-SSR (20-23)

(T-20) How are by the personal student judgment, limited schooling and obligations because of health?

\begin{tabular}{lcccc}
\hline SAMPLES & TOT (SRB-2) & Boys-2 & Girls-2 & TOT (GRE-1) \\
\hline No restrictions & $\mathbf{6 1 . 5 \% ( 4 ) *}$ & $\mathbf{6 1 . 5 \%}$ & $\mathbf{6 1 . 5 \%}$ & $(-)$ \\
Partially restricted & $30.8 \%$ & $30 \%$ & $30.8 \%$ & $\mathbf{6 6 . 7 \%}(\mathbf{3}) *$ \\
Occasionally restricted & $7.7 \%$ & $7.7 \%$ & $7.7 \%$ & $33.3 \%$ \\
\hline
\end{tabular}

(U-21) On the personal judgment, haw was limited activities with students because of a medical condition?

\begin{tabular}{lcccc}
\hline SAMPLES & TOT (SRB-2) & Boys-2 & Girls-2 & TOT (GRE-1) \\
\hline No restrictions & $\mathbf{6 6 . 7 \% ( 4 ) *}$ & $\mathbf{6 4 . 3 \%}$ & $\mathbf{6 9 . 2 \%}$ & $(-)$ \\
Somewhat limited & $7.4 \%$ & $14.3 \%$ & $(-)$ & $\mathbf{6 6 . 7 \%}(\mathbf{3}) *$ \\
Occasionally limited & $22.2 \%$ & $21.4 \%$ & $23.1 \%$ & $33.3 \%$ \\
Completely restricted & $3.7 \%$ & $(-)$ & $7.7 \%$ & $(-)$
\end{tabular}

(V-22) What is the emotional state of students in relation to restrictions on health grounds?

\begin{tabular}{lcccc}
\hline SAMPLES & TOT $($ SRB-2) & Boys-2 & Girls-2 & TOT $(\mathrm{GRE}-1)$ \\
\hline Great mood & $\mathbf{5 5 . 6 \% ( 4 ) *}$ & $\mathbf{5 7 . 1 \%}$ & $\mathbf{5 3 . 8 \%}$ & $(-)$ \\
Good mood & $29.6 \%$ & $35.7 \%$ & $23.1 \%$ & $40 \%$ \\
Changing mood & $11.1 \%$ & $7.1 \%$ & $15.4 \%$ & $\mathbf{6 0 \%}(\mathbf{2}) *$ \\
Depression & $3.7 \%$ & $(-)$ & $7.7 \%$ & $(-)$ \\
\hline
\end{tabular}

(W-23) What is the behavior of students in relation to the restrictions on the health grounds?

\begin{tabular}{lcccc}
\hline SAMPLES & TOT $($ SRB-2) & Boys-2 & Girls-2 & TOT (GRE-1) \\
\hline Active attitude & $\mathbf{6 4 . 3 \% ( 4 ) *}$ & $\mathbf{7 1 . 4 \%}$ & $\mathbf{6 1 . 5 \%}$ & $(-)$ \\
Benevolent & $17.8 \%$ & $7.1 \%$ & $30.8 \%$ & $\mathbf{6 0 \%}(\mathbf{3}) *$ \\
Occasional outbursts & $10.7 \%$ & $21.4 \%$ & $(-)$ & $\mathbf{4 0 \%}(\mathbf{2}) *$ \\
Hostile & $7.2 \%$ & $(-)$ & $7.7 \%$ & $(-)$ \\
\hline
\end{tabular}

Hostile

Note: In parenthesis are marked statements modalities up (1)* to (4)*, within some items, which contributed (ctrb.\%) to the statistically significant between "groups" differences: MANOVA ( $\mathrm{F}=13.995, \mathrm{p}=.000)$; DISCRA $(\mathrm{F}=13.995, \mathrm{p}=.000)$. Homogeneity: GRE-1: 15/15 (100\%); SRB-2: 25/30 (83.3\%). Ctrb. (\%): U-21 (75.8), V-22 (19.9), W-23 (2.25), T-20 (2.1). 
The Scale of Social Roles Implementation - G-SSR (20-23), presented relative values within items (T20, U21, V22, W23), and provided statements, which do not point out a significant gender difference between local sub-samples (Boys-2; Girls-2), while in the majority of statements, the respondents opted for the highest modality intensity, which means that there are no limitations when considering the combined impact of emotions and behaviors for the realization of a social role, with some prevalence of higher percentage of statements in Boys-2 sub-sample, except in item U21, with some prevalence of higher percentage of statements in Girls-2 sub-sample.

H - C7 - The self evaluation scale: (X24, Y25, Z26, AA27, AB28). Self-assessment is a multi-dimensional phenomenon that occurs during pre-adolescence, and shapes and redefines during one's life-time, and includes three essential components: social security (confidence), academic skills and self-esteem. The Scale, applied in this questionnaire, is designed as a 4-point scale and includes the following dimensions: satisfaction with the

Table 7 The Self Evaluation Scale - H-SES (24-28)

\begin{tabular}{lcccc}
\hline (X-24) & \multicolumn{4}{c}{ How satisfied are students with their academic achievement? } \\
\hline SAMPLES & TOT (SRB-2) & Boys-2 & Girls-2 & TOT (GRE-1) \\
\hline Very satisfied & $\mathbf{6 3 \% ( 4 ) *}$ & $\mathbf{7 1 . 4 \%}$ & $38.5 \%$ & $6.7 \%$ \\
Mostly satisfied & $30 \%$ & $21.4 \%$ & $\mathbf{5 3 . 8 \%}$ & $\mathbf{8 6 . 7 \%}(3)^{*}$ \\
Mostly dissatisfied & $3.5 \%$ & $7.1 \%$ & $7.7 \%$ & $6.7 \%$ \\
Very dissatisfied & $3.5 \%$ & $(-)$ & $(-)$ & $(-)$ \\
\hline (Y-25) & \multicolumn{4}{c}{ How the students' are satisfied with their physical abilities? } \\
\hline SAMPLES & TOT (SRB-2) & Boys-2 & Girls-2 & TOT (GRE-1) \\
\hline Very satisfied & $\mathbf{4 6 . 4 \% ( 4 ) *}$ & $\mathbf{5 7 . 1 \%}$ & $42.8 \%$ & $6.7 \%$ \\
Mostly satisfied & $\mathbf{4 6 . 4 \%}$ & $42.9 \%$ & $\mathbf{5 0 \%}$ & $\mathbf{9 3 . 3} \%(3)^{*}$ \\
Mostly dissatisfied & $7.2 \%$ & $(-)$ & $7.2 \%$ & $(-)$ \\
Very dissatisfied & $(-)$ & $(-)$ & $-)$ & $(-)$ \\
\hline (Z-26) & How are the students satisfied with their appearance? \\
\hline SAMPLES & TOT (SRB-2) & Boys-2 & Girls-2 & TOT (GRE-1) \\
\hline Very satisfied & $\mathbf{6 2 . 9 \% ( 4 ) *}$ & $\mathbf{8 5 . 7 \%}$ & $\mathbf{3 8 . 5 \%}$ & $(-)$ \\
Mostly satisfied & $22.2 \%$ & $14.3 \%$ & $30.8 \%$ & $6.7 \%$ \\
Mostly dissatisfied & $7.4 \%$ & $(-)$ & $15.4 \%$ & $\mathbf{8 6 . 7 \%}(\mathbf{3} \%$ \\
Very dissatisfied & $7.4 \%$ & $(-)$ & $15.4 \%$ & $6.7 \%$ \\
\hline
\end{tabular}

(AA-27)What is the student's personal assessment in relation to the ability of conformity with friends and family members?

\begin{tabular}{|c|c|c|c|c|}
\hline SAMPLES & TOT (SRB-2) & Boys-2 & Girls-2 & TOT (GRE-1) \\
\hline Very satisfied & $59 \%(4) *$ & $57.1 \%$ & $61.5 \%$ & $6.7 \%$ \\
\hline Mostly satisfied & $33 \%$ & $35.8 \%$ & $30.8 \%$ & $\mathbf{8 6 . 7} \%(3)^{*}$ \\
\hline Mostly dissatisfied & $8 \%$ & $7.1 \%$ & $7.7 \%$ & $6.7 \%$ \\
\hline Very dissatisfied & $(-)$ & $(-)$ & $(-)$ & $(-)$ \\
\hline (AB-28) & \multicolumn{4}{|c|}{ How are the students satisfied with overall life? } \\
\hline SAMPLES & TOT (SRB-2) & Boys-2 & Girls-2 & TOT (GRE-1) \\
\hline Very satisfied & $74 \%(4) *$ & $78.6 \%$ & $69 \%$ & $6.7 \%$ \\
\hline Mostly satisfied & $14.8 \%$ & $21.4 \%$ & $8 \%$ & $80 \%(3) *$ \\
\hline Mostly dissatisfied & $7.5 \%$ & $(-)$ & $15 \%$ & $13.3 \%$ \\
\hline Very dissatisfied & $3.7 \%$ & $(-)$ & $8 \%$ & $(-)$ \\
\hline
\end{tabular}


school and physical abilities; satisfaction with appearance; satisfaction with the ability to conform with others, as well as with family members; satisfaction with one's overall life. Answers vary from "very satisfied" to "very dissatisfied" whereas the low score points out that a child is very dissatisfied, and the high points out that the child is very satisfied with its abilities, appearance, family relationships and overall satisfaction with life.

The Self-Evaluation Scale - H-SES (24-28), presented relative values within items (X24, Y25, Z26, AA27, AB28), and provided statements, pointing out some numerical gender differences between local sub-samples (Boys-2; Girls-2), while for the majority of items (boys-2) the sub-sample opted for a high score (very satisfied), with higher \% in the following dimensions: satisfaction with the school physical abilities; satisfaction with appearance; satisfaction with the ability to conform with others, as well as with family members; satisfaction with overall life. The Girls-2 sub-sample does not provide such confidence in social security, academic skills and self-esteem, except when it comes to the ability to conform with others.

I-C $\mathbf{C}_{\mathbf{8}}$ - The scale of the mental health: (AC29, AD30) measures the frequency of positive and negative states. To analyze the frequency of answers, a 4-point scale of intensity was used, on which answers vary from "all the time/continuous" to "never". The low score of mental health is based on talk about feelings of anxiety and depression that are present continuously, while a high score means that the child is calm and happy.

Table 8 The Mental Health Scale - I-MHS (29-30)

\begin{tabular}{lcccc}
\hline \multicolumn{5}{l}{ (AC-29)How often are students worried because of their mental health condition? } \\
\hline SAMPLES & TOT (SRB-2) & Boys-2 & Girls-2 & TOT (GRE-1) \\
\hline Never & $\mathbf{6 7 . 8 \% ( 4 ) *}$ & $\mathbf{6 1 . 5 \%}$ & $\mathbf{7 3 . 3 \%}$ & $6.7 \%$ \\
Sometimes & $28.6 \%$ & $30.7 \%$ & $26.7 \%$ & $\mathbf{7 3 . 3 \%}(\mathbf{3}) *$ \\
Almost always & $(-)$ & $(-)$ & $(-)$ & $26.7 \%(2)^{*}$ \\
All the time & $3.6 \%$ & $7.7 \%$ & $(-)$ & $(-)$
\end{tabular}

\begin{tabular}{lcccc}
\hline \multicolumn{4}{l}{ (AD-30)How often are students happy with their physical and medical conditions? } \\
\hline SAMPLES & TOT (SRB-2) & Boys-2 & Girls-2 & TOT (GRE-1) \\
\hline Never & $13 \%$ & $15.4 \%$ & $13.3 \%$ & $6.7 \%$ \\
Sometimes & $17.8 \%$ & $15.4 \%$ & $20.1 \%$ & $\mathbf{6 0 \%}(\mathbf{3}) *$ \\
Almost always & $25 \%$ & $15.4 \%$ & $\mathbf{3 3 . 3 \%}$ & $33.3 \%$ \\
All the time & $\mathbf{4 4 . 2 \% ( 1 ) *}$ & $\mathbf{5 3 . 8 \%}$ & $\mathbf{3 3 . 3 \%}$ & $(-)$ \\
\hline
\end{tabular}

Note: In parenthesis are marked statements modalities up (1)* to (4)*, within some items, which contributed (ctrb.\%) to the statistically significant between "groups" differences: MANOVA ( $\mathrm{F}=16.001, \mathrm{p}=.000)$; DISCRA ( $\mathrm{F}=19.048$, p=.000). Homogeneity: GRE-1: 14/15 (93.3\%); SRB-2: $25 / 30$ (83.3\%). Ctrb. (\%): AC-29 (81.9), AD-30 (18.1)

The Mental Health Scale - IMHS (29-30), presented relative values within items (AC29, AD30), and provided statements, pointing out on some numerical gender differences between local sub-samples (Boys-2; Girls-2). In both cases no statements were presented on the low score of mental health, only Girls-2 respondents are more confident when talking about feelings, while Boys- 2 respondents have a higher score when it comes to about happiness with their physical and medical conditions, which means that the children are calm and happy. 
J-C $\mathbf{9}$ - The scale of behaviour: (AE31, AF32, AG33). Frequency of problems related to behavior are assessed on a 4-point scale of intensity, with responses ranging from-to: "always-very often-sometimes-never". The scale is designed so that it includes four dimensions of behavior: aggression, delinquency, hyperactivity (impulsivity), and social rejection. A low score indicates a potentially aggressive, immature and delinquent behavior, while a high score means that the child never manifests such behavior.

Table 9 The Scale of Behavior - J-SBH (31-33)

\begin{tabular}{lcccc}
\hline \multicolumn{5}{l}{ (AE-31) How often do students exhibit aggressive behavior? } \\
\hline SAMPLES & TOT (SRB-2) & Boys-2 & Girls-2 & TOT (GRE-1) \\
\hline Never & $\mathbf{4 4 . 4 \% ( 4 ) *}$ & $\mathbf{5 8 . 3 \%}$ & $33.3 \%$ & $6.7 \%$ \\
Sometimes & $\mathbf{4 4 . 4 \%}$ & $33.3 \%$ & $\mathbf{5 3 . 3 \%}$ & $\mathbf{8 0 \%}(\mathbf{3}) *$ \\
Very often & $11.2 \%$ & $8.3 \%$ & $13.3 \%$ & $13.3 \%$ \\
\hline (AF-32) How often is student sanctioned for & delinquent behavior? & \\
\hline SAMPLES & TOT (SRB-2) & Boys-2 & Girls-2 & TOT (GRE-1) \\
\hline Never & $\mathbf{( 7 0 . 4 \% ) *}$ & $\mathbf{7 6 . 9 \%}$ & $\mathbf{6 0 \%}$ & $6.7 \%$ \\
Sometimes & $25.9 \%$ & $23.1 \%$ & $26.7 \%$ & $\mathbf{6 0 \%}(\mathbf{3})^{*}$ \\
Very often & $(-)$ & $(-)$ & $(-)$ & $33.3 \%(2)^{*}$ \\
Always & $3.7 \%$ & $(-)$ & $6.7 \%$ & $(-)$ \\
\hline (AG-33) How often do students exhibit hyperactivity/impulsivity? & \\
\hline SAMPLES & TOT (SRB-2) & Boys-2 & Girls-2 & TOT (GRE-1) \\
\hline Never & $\mathbf{3 8 . 5 \% ( 4 ) *}$ & $\mathbf{3 8 . 5 \%}$ & $\mathbf{3 3 . 3 \%}$ & $6.7 \%$ \\
Sometimes & $26.9 \%$ & $23 \%$ & $26.7 \%$ & $\mathbf{6 6 . 7 \%}(\mathbf{3}) *$ \\
Very often & $34.6 \%$ & $38.5 \%$ & $26.7 \%$ & $26.7 \%$ \\
\hline
\end{tabular}

Note: In parenthesis are marked statements modalities up (1)* to (4)*, within some items, which contributed (ctrb.\%) to the statistically significant between "groups" differences: MANOVA ( $\mathrm{F}=14.65, \mathrm{p}=.000)$; DISCRA $(\mathrm{F}=14.29, \mathrm{p}=.000)$. Homogeneity: GRE-1: 14/15 (93.3\%); SRB-2: 23/30 (76.7\%). Ctrb. (\%): AF-32 (80.845), AG-33 (14.05), AE-31 (5.11).

The Scale of Behavior J-SBH (31-33), presented relative values within items (AE31, AF32, AG33), and provided statements, pointing out some numerical gender difference between local sub-samples (Boys-2; Girls-2). Boys-2 respondents have a higher score on all the items, then Girls-2 respondents, which means that the children did not manifest such behavior as aggression, delinquency, impulsivity, and social rejection, with some exception in the Girls-2 sub-sample, when considering statements on aggressive behavior (sometimes), with a high percentage $(53.3 \%)$, which may point out a contemporary feminist gender role in society.

K-C $\mathbf{C}_{10}$ - The scale of family activities and family relationships (AH34, AI35, AJ36). The family situation is of great importance for children's health, and it is also known that a child's health condition can affect family relationships. With this (Q), the authors wanted to assess the level of restrictions that families experience because of their children's health. This 4-point intensity scale is designed to measure the frequency of disorders/restrictions in common family activities, which may be conditioned by physical and/or emotional problems, as well as with attention disorders and child behavior. Replies range from "often" to "never", where the low score points out that the child's health has often disturbed the family activities, or caused family tensions, while a high score means that the child's health never produced tensions or disturbed ordinary activities. For the assessment of family 
connections one item has been developed, where the respondent should answer how well the members of his family agree amongst themselves, where the responses vary from "excellent" to "bad". The low score means that the ability to connection is assessed as "bad", whereas a high score points out an excellent ability for family connection.

Table 10 The Scale of Family activities and Relationships - K-SFAR (34-36)

\begin{tabular}{lcccc}
\hline \multicolumn{5}{l}{ (AH-34) How the student's environment } \\
\hline SAMPLES & TOT (SRB-2) & Boys-2 & Girls-2 & TOT (GRE-1) \\
\hline Excellent & $\mathbf{5 3 . 6 \% ( 4 ) *}$ & $\mathbf{4 6 . 1 \%}$ & $\mathbf{6 0 \%}$ & $6.7 \%$ \\
Very good & $28.6 \%$ & $38.5 \%$ & $20 \%$ & $\mathbf{6 0} \%(3)^{*}$ \\
Good & $10.7 \%$ & $15.4 \%$ & $6.7 \%$ & $33.3 \%$ \\
Poor & $7.1 \%$ & $(-)$ & $13.3 \%$ & $(-)$ \\
\hline (AI-35) How the child's health disrupted normal family activities, cause family tension? \\
\hline SAMPLES & TOT (SRB-2) & Boys-2 & Girls-2 & TOT (GRE-1) \\
\hline Never & $\mathbf{7 5 \% ( 4 ) *}$ & $\mathbf{8 5 \%}$ & $\mathbf{6 6 . 7 \%}$ & $6.7 \%$ \\
Sometimes & $17.8 \%$ & $15 \%$ & $20 \%$ & $\mathbf{8 6 . 7} \%(3)^{*}$ \\
Often & $3.6 \%$ & $(-)$ & $6.7 \%$ & $6.7 \%$ \\
Always & $3.6 \%$ & $(-)$ & $6.7 \%$ & $(-)$ \\
\hline (AJ-36) How well the student's family members agree among themselves? & \\
\hline SAMPLES & TOT (SRB-2) & Boys-2 & Girls-2 & TOT (GRE-1) \\
\hline Excellent & $\mathbf{7 1 . 5 \% ( 4 ) *}$ & $\mathbf{6 9 . 2 \%}$ & $\mathbf{7 3 . 3 \%}$ & $6.7 \%$ \\
Very good & $17.8 \%$ & $23.1 \%$ & $13.3 \%$ & $40 \%(3)^{*}$ \\
Good & $7.1 \%$ & $(-)$ & $13.3 \%$ & $\mathbf{5 3 . 3 \% ( 2 ) *}$ \\
Poor & $3.6 \%$ & $\mathbf{7 . 7 \%}$ & $(-)$ & $(-)$ \\
\hline
\end{tabular}

Note: In parenthesis are marked statements modalities up (1)* to (4)*, within some items, which contributed (ctrb.\%) to the statistically significant between "groups" differences: MANOVA ( $\mathrm{F}=18.498, \mathrm{p}=.000)$; DISCRA ( $\mathrm{F}=18.046, \mathrm{p}=.000)$. Homogeneity: GRE-1: 14/15 (93.3\%); SRB-2: $27 / 30$ (90\%). Ctrb. (\%): AJ-36 (61.4), $\mathrm{AI}-35$ (36.0), AH-34 (2.6).

The Scale of Family activities and Family unity - K-SFAR (34-36) presented relative values within items (AH34, AI35, AJ36), and provided statements, pointing out some numerical gender difference between local sub-samples (Boys-2; Girls-2). Girls-2 respondents, unlike the Boys- 2 respondents, have a majority of higher scores on all the items, except in (AI-35), where Girls-2 statements are divided within all statements modalities. Replies range from "never" (66.7\%), "sometimes" (20\%), "often" (6.7\%) to "always" $(6.7 \%)$, where the low score points out that the child health often has disturbed the family activities, or caused family tensions, while a high score means that the child's health never produced tensions nor disturbed ordinary activities.

L-C $\mathbf{C}_{\mathbf{1 1}}$ - The scale of change in health - comprises item AK37. This scale registers the health changes over the previous year. Answers range from "much better now" to "much worse now", so that the low score indicates deterioration and a high score the improvement of health. 
Table 11 The Scale of Health Change - L-SHC (37)

\begin{tabular}{|c|c|c|c|c|}
\hline \multicolumn{5}{|c|}{ (AK-37) How the student assesses health changes over the last year? } \\
\hline SAMPLES & TOT (SRB-2) & Boys-2 & Girls-2 & TOT (GRE-1) \\
\hline Much better now & $53.5 \%(4) *$ & $76.9 \%$ & $33.3 \%$ & $20 \%$ \\
\hline Improvement tendency & $39.3 \%$ & $23.1 \%$ & $53.3 \%$ & $80 \%(3) *$ \\
\hline Tendency of worsening & $3.6 \%$ & $(-)$ & $6.7 \%$ & $(-)$ \\
\hline Much worse now & $3.6 \%$ & $(-)$ & $6.7 \%$ & $(-)$ \\
\hline
\end{tabular}

The Scale of Health Change - L-SHC (37), with only one item (AK-37), for the local Boys-2 sub-sample, the majority of respondents opted for the statements on health changes over the last year as "much better now" (76.9\%), which is significantly different from those options in Girls-2 sub-sample, where the majority of the respondents opted for the statements on "tendency of improvement" (53.3\%), and only 1/3rd opted for the statement "much better now" (33.3\%), so that the low score indicates deterioration, and a high score the improvement of health. These options point out gender differences in this segment of the scale which evaluates the change in health.

Based on the above mentioned, it is evident that it is possible to include the scaled data in a multivariate analysis of variance (MANOVA), discriminant analysis (DISCRA) and other parametric procedures and methods. Of the univariate methods Roy's test, Pearson's coefficient of contingency $(\chi)$ and multiple correlation coefficient $(\mathrm{R})$ were applied. On the basis of elaborated MANOVA and DISCRA comparative analyses and the obtained values (F; p), we must reject the hypotheses $\mathrm{H}_{1}$ and $\mathrm{H}_{2}$ in all the segments of the $(\mathrm{Q})$, and accept the alternative hypotheses $\mathrm{A}_{1}$, and $\mathrm{A}_{2}$, which means that there is a difference and clearly defined border between "groups of respondents" (GRE-1; SRB-2) in all segments of Q, which assesses the Health and Social Wellness (HSW), and Quality of life of older elementary school students, or "groups" of different ethnic origin.

\section{CONCLUSIONS}

It can be concluded from the obtained results, that the factor analysis of the main components with an oblimin transformation is a very suitable method for determining motor skills.

However, apart from the fact that at this moment this method is considered to be an optimal exploration procedure, a number of further studies are needed that would continually complement the knowledge about the methods and laws of man's motor skills.

The applied Questionnaire (Q) for the assessment of the Quality of life, i.e., the Health and Social welfare (HSW) contains 11 segments and 37 items within them, with the possibility of the respondents choosing between four modalities of offered answers on the Likert-type scale (degree1-4). On the basis of the conducted mathematical - statistical procedures, in the comparative analysis of the results and their interpretation, it can be concluded that significant differences were determined. The characteristics and homogeneity of the groups have mostly contributed to the between-groups differences in relation to items of particular segments, the frequency of responses, i.e., a different option for individual 
modalities of items. Respondents from GRE-1 have lower variability of statements, which did not have an important intensity of modalities $(2 *-3 *)$ while the participants of SRB-2, with one exception $\left(1^{*}\right)$, opted for the highest intensity of response modality $\left(4^{*}\right)$ for the most items within particular segments, which has significantly contributed to the established differences.

\section{REFERENCES}

Franchini, E., Sterkowicz, S., Meira Jr, C. M., Gomes, F. R. F., \& Tani, G. (2008). Technical variation in a sample of high level judo players. Perceptual and Motor Skills, 106(3), 859-869.

Franchini, E., Takito, M.Y., Kiss, M.A.P.D.M., \& Sterkowicz, S. (2005). Physical fitness and anthropometrical differences between elite and non-elite judo players. Biology of Sport, 22(4), 315-328.

Franchini, E., Yuri Takito, M., Cavinato, C.C., Matheus, L., Bertuzzi, R.C.M., \& Vieira, D.E.B. (2001.a) Relationship Between Morphological, Physiological and Technical Variables in High Level College Judo Players. In 2nd IJF World Judo Conference Munich, Germany.

Franchini, E., Yuri Takito, M., Dal Molin Kiss, M.A.P., \& Sterkowicz, S. (2001b). Physical Fitness and Anthropometric Differences Between Elite and Nonelite Judo Players. In 2nd IJF World Judo Conference Munich, Germany.

Krstulović, S., Žuvela, F., \& Katić, R. (2006). Biomotor systems in elite junior judoists. Collegium antropologicum, 30(4), 845-851.

Kvrgić, S. (2001). Kvalitet života školske dece i omladine. (The quality of life of school children and youth). Belgrade: Andrejević Foundation, TODRA. (in Serbian)

Milić, M., Čular, D., Milavić, B., Tomas, T., \& Vojković, T. (2015). The influence of conative characteristics on success in young taekwondo competitors. Research in Physical Education, Sport and Health, 4(1), 27-36.

Obminski, Z., Litwiniuk, A., Staniak, Z., Zdanowicz, R., \& Weimo, Z. (2015). Intensive specific maximal judo drills improve psycho-motor ability but may impair hand grip isometric strength. Ido Movement for Culture. Journal of Martial Arts Anthropology, 15(2), 52-58.

Popović, R. (2015). Physical education of children with medical conditions. International Scientific Conference "FIS Communications 2015" in Physical Education, Sports and Recreation. Book of Proceedings, pp. 210-216. University of Nis, Faculty of Sport and Physical Education.

Popovic, D. (1990) Martial Arts I (Judo and Self-Defense), (textbook), University of Nis. In Serbian.

Popović, J., Popović, R., Mutavdžić, V. (2016). The Social Characteristics of Folklore Dancers and Their Family Members in Some Manifest Stratification Variables: Gender Differences. Slovak Journal of Sport Science, 1(2), 15-27.

Popović, J., Popović, R., Mutavdžić, V. (2016). Karakteristike socijalnog statusa folklornih plesača i članova njihove porodice $\mathrm{u}$ nekim manifestnim stratifikacijskim varijablama: Polne razlike. VI Međunarodna konferencija "SPORTSKE NAUKE I ZDRAVLJE", (11.03.2016), Panevropski univerzitet "Apeiron" Banja Luka, Bosna i Hercegovina: Zbornik radova u štampi: (str. 1-10 manuscript), Collection of Papers in print (in Serbian)

Popović, R., Samouilidou, E., Dolga, M. (2015). The quality of life of school age children and youth. FSFVConference, Belgrade-2015. Book of Proceedings (pp. 508-522), University of Belgrade, Faculty of Sport and Physical Education.

Samouilidou, A.E. (2004). Stimulacija motoričkog razvoja dece sa mentalnom retardacijom (Stimulation of the motor development of children with mental retardation). Belgrade: Andrejević Foundation, TODRA. (in Serbian)

Sertić, H., Segedi, I., \& Žvan, M. (2007). Relations of certain anthropometric variables with the performance quality of throwing techniques. Kinesiologia Slovenica, 13(1), 48-60.

Sertic, H., Sterkowicz, S., \& Vuleta, D. (2009). Influence of latent motor abilities on performance in judo. Kinesiology, 41(1), 76-87.

Mimica, A., \& Bogdanović, M. (2007). Sociološki rečnik (Dictionary of Sociology). Zavod za udžbenike i nastavna sredstva. Belgrade (in Serbian)

Taras, H. (2005). Physical activity and student performance at school. Journal of School Health, 75(6), 214-218. 


\section{PRIMENA UPITNIKA O KVALITETU ŽIVOTA, ZDRAVLJU I SOCIJALNOM BLAGOSTANJU UČENIKA OSNOVNE ŠKOLE: MEĐUKULTURALNE I POLNE SPECIFIČNOSTI}

Predmet ove studije je uporedno sagledavanje mogućnosti primene fizičkog vaspitanja kod dece sa zdravstvenim tegobama i prikaz stanja kod dečaka i devojčica. Razumevanjem ovog problema se stvaraju preduslovi za realizaciju telovežbenog procesa i moguću integraciju dece $u$ nastavu fizičkog vaspitanja, prema vidu zdravstvenih nedostataka. Procena kvaliteta života vrši se na tri nivoa. Prvi je na nivou stavki-tvrdnji. Na drugom nivou stavke se posmatraju kao čestice u okviru skala koje pokrivaju različite dimenzija zdravlja i kvaliteta života. Skorovi svake skale transformišu se u standardizovane vrednosti (1-4), što olakšava interpretaciju rezultata. Treći je nivo ukupnog fizičkog i psihosocijalnog zdravlja, polazeći od skorova pojedinačnih skala zdravlja. MANOVA i DISCRA je primenjena radi uporedne analize kulturnih i polnih specifičnosti u okviru pojedinih segmenata skale Upitnika QLHSW (Kvalitet života, zdravlja i socijalnog blagostanja). Analizom podataka evidentirane su izvesne kulturne i polne specifičnosti i mogućnosti primene fizičke aktivnosti kod dece sa zdravstvenim tegobama, sa posebnim prikazom stanja kod dečaka $i$ devojčica različitog kulturnog i socijalnog porekla u Srbiji i Severno-Egejskom regionu Grčke.

Ključne reči: školska deca,poremećaji zdravlja, upitnik, samoprocena, kulturne i polne specifičnosti, uporedna analiza 